\title{
Modelling and mapping the local distribution of representative species on the Le Danois Bank, El Cachucho Marine Protected Area (Cantabrian Sea)
}

\author{
Ana García-Alegre ${ }^{\mathrm{a}, *}$, Francisco Sánchez ${ }^{\mathrm{a}}$, María Gómez-Ballesteros ${ }^{\mathrm{b}}$, Hilmar Hinz ${ }^{\mathrm{c}}$, \\ Alberto Serrano ${ }^{a}$, Santiago Parra ${ }^{\mathrm{d}}$ \\ a Instituto Español de Oceanografía, C.O. de Santander, Promontorio San Martín s/n, Apdo. 240, 39080 Santander, Spain \\ ${ }^{\mathrm{b}}$ Instituto Español de Oceanografía, C.O. de Madrid, C/Corazón de María 8, 28002 Madrid, Spain \\ ' School of Ocean Sciences, University of Wales, Bangor, Askew Street, Menai Bridge LL59 5AB, Wales, UK \\ d Instituto Español de Oceanografía, C.O. de A Coruña, P Marítimo Alcalde Francisco Vázquez 10, 14 15001A Coruña, Spain
}

\section{A R T I C L E I N F O}

Available online 5 January 2014

Keywords:

Le Danois Bank

El Cachucho MPA

MAXENT

Spatial modelling

Habitat suitability

\begin{abstract}
A B S T R A C T
The management and protection of potentially vulnerable species and habitats require the availability of detailed spatial data. However, such data are often not readily available in particular areas that are challenging for sampling by traditional sampling techniques, for example seamounts. Within this study habitat modelling techniques were used to create predictive maps of six species of conservation concern for the Le Danois Bank (El Cachucho Marine Protected Area in the South of the Bay of Biscay). The study used data from ECOMARG multidisciplinary surveys that aimed to create a representative picture of the physical and biological composition of the area. Classical fishing gear (otter trawl and beam trawl) was used to sample benthic communities that inhabit sedimentary areas, and non-destructive visual sampling techniques (ROV and photogrammetric sled) were used to determine the presence of epibenthic macrofauna in complex and vulnerable habitats. Multibeam echosounder data, highresolution seismic profiles (TOPAS system) and geological data from box-corer were used to characterize the benthic terrain. ArcGIS software was used to produce high-resolution maps $\left(75 \times 75 \mathrm{~m}^{2}\right)$ of such variables in the entire area. The Maximum Entropy (MAXENT) technique was used to process these data and create Habitat Suitability maps for six species of special conservation interest. The model used seven environmental variables (depth, rugosity, aspect, slope, Bathymetric Position Index (BPI) in fine and broad scale and morphosedimentary characteristics) to identify the most suitable habitats for such species and indicates which environmental factors determine their distribution. The six species models performed highly significantly better than random ( $p<0.0001$; Mann-Whitney test) when Area Under the Curve (AUC) values were tested. This indicates that the environmental variables chosen are relevant to distinguish the distribution of these species. The Jackknife test estimated depth to be the key factor structuring their distribution, followed by the seabed morpho-sedimentary characteristics and rugosity variables. Three of the species studied (Asconema setubalense, Callogorgia verticillata and Helicolenus dactylopterus) were found to have small suitable areas as a result of being restrictive species related to the environmental characteristics of the top of the bank. The other species (Pheronema carpenteri, Phycis blennoides and Trachyscorpia cristulata), which were species less restrictive to the environmental variables used, had highly suitable areas of distribution. The study provides high-resolution maps of species that characterize the habitat of two communities included in OSPAR and NATURA networks, whose distributions corroborate the adequate protection of this area by the management measures applied at present.
\end{abstract}

(c) 2014 Elsevier Ltd. All rights reserved.

\section{Introduction}

Seamounts are deep-sea areas that can exhibit high biodiversity and high levels of endemism (Aguilar et al., 2006; Probert, 1999)

\footnotetext{
* Corresponding author. Tel.: + 34 942291060; fax: + 34942275072.

E-mail address: ana.garcia@st.ieo.es (A. García-Alegre).
}

depending on habitat composition (Rowden et al., 2010). This makes these marine features potentially vulnerable to fishing impacts and other human activities (Stocks, 2004; Morato et al., 2005) and therefore exacerbates their need for protective conservation measures (Morato et al., 2006). Currently Marine Protected Areas (MPAs) are being created to conserve and manage seamounts. One example of this is the case study presented here, the Le Danois Bank, an extensive offshore bank and seamount declared as a MPA 